\title{
BRATI GLEDALIŠČE: REPLIKE IZ ANTIKE
}

\author{
JERA IVANC
}

\section{Draga Melpomena,}

zelo me veseli, da sta s sestro Talijo tako bogato pognojili dramsko in gledališko setev na slovenskem v preteklem letu. Koliko izdaj in koliko gledaliških dogodkov! Ajshilove Pribežnice, Agamemnon, Daritev na grobu in Evmenide, Sofoklov Ajant, Evripidova Helena, Plavtovi Osli in Dvojčka ter Senekova Medeja: dve gledališči, tri založbe, štiri knjige, pet prevajalcev, devet dramskih del in triinštirideset dramskih igralcev. Vse te številke so zelo lepe, sploh če prišteješ zraven še urednike, režiserje, dramaturge, lektorje, scenografe, kostumografe, asistente, tehnične poklice, bralce in gledalce. Lepe so tudi številke gledališkega projekta klasičnih gimnazij Klasiki na odru: eno društvo, štiri mesta, šest gimnazij, sedem enodejank in štiriinsedemdeset nastopajočih dijakov. Gledališče res daleč seže. Če bomo tako nadaljevali, bomo imeli do leta 2013, ko praznujemo 150 letnico izdaje prvega prevoda grške tragedije (Valjavčev Ajant), prevedene vse grške tragedije, malce kasneje pa že kar vso dramatiko. Pa ne samo to. Ker s ponudbo ponavadi naraste tudi povpraševanje, sploh če gre za kvalitetno robo, bodo antične in humanistične vsebine tako vseprisotne, da bomo kmalu dohiteli Veliko Britanijo, kjer jim komaj še uspe sproti izšolati dovolj kadrov! Ha ha! Si lahko predstavljaš? Jaz si lahko.

No, ampak hitimo počasi in prišli bomo daleč. $V$ statutu Društva za antične in humanistične študije, katerega aktivni član sem - kot v duhu kolektivne zavesti vedno znova poudarjam -, piše:

"Društvo si prizadeva za širjenje antične (grške in rimske) kulture, ki predstavlja temelj evropske kulture. Aktivno sodeluje s pristojnimi organi v zvezi z učnimi in študijskimi programi, ki vključujejo pouk latinskega jezika in grškega jezika ter njunih književnosti. Pospešuje razvoj znanstvenih raziskovanj na področju antike in antične dediščine ter popularizira strokovne, znanstvene in didaktično-pedagoške dosežke s področja antike in antične dediščine.«

Torej: $\operatorname{Vr}(i)$ nimo se! Na pobudo profesorja Babiča smo lani zasnovali projekt Klasiki na odru in glede na to, da je bil za veliko večino sodelujočih, dijakov in mentorjev, to prvi aktivni stik z gledališko ustvarjalnostjo, so bili rezultati presenetljivi. 
Po drugi strani pa so mi dali misliti. Besedilne predloge - šlo je za kratke priredbe grških mitov oz. dramskih besedil avtorice Geraldine McCaughrean: The Greeks on Stage, ki so jih dijaki prevedli sami - so bile dramaturško in gledališko šibke, s seznami scenskih elementov, rekvizitov in kostumov ter dobronamernimi napotki „Vzameš rjuho" etc. pa so ustvarjalnost dijakov prej zatrle kot spodbudile; le redke skupine so se spustile $\mathrm{v}$ dialog $\mathrm{z}$ materialom in ga skušale po svoje pregnesti. Imeli smo pač premalo časa za pogovor o gledališču. Za pogovor o dobrem gledališču, ki je prostor konflikta, poligon za dialog, ne le med dramskimi osebami, temveč vsega $\mathrm{z}$ vsem, kar je bilo, in kar je - v besedi, mesu ali misli. Zato ne more biti posnetek resničnosti (še vedno mi nisi odgovorila, ali je bil v Poetiki na delu škrat, ki je $\mu \nu \tilde{\eta} \sigma \tau \iota \varsigma$

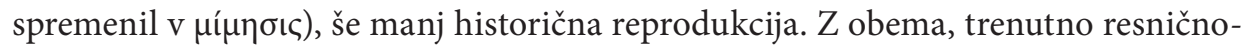
stjo in preteklo tradicijo, je v dialogu, konfliktu, opoziciji, nikoli ne stagnira. Zahteva zahtevnega ustvarjalca in zahtevnega gledalca. Kajti - spet bom navdušeno citirala Vernanta - »edino gledalcu je lahko govorica teksta jasna na vseh nivojih, z vso svojo mnogoznačnostjo in $\mathrm{z}$ vsemi svojimi dvoumnostmi. /.../ Sporočilo tragedije se prenese le toliko, kolikor gledalec odkrije dvoumnost besed, vrednot, človeka, kolikor sprevidi konfliknost sveta in kolikor opusti svoja prejšnja prepričanja, sprejme negotov pogled na svet in skozi predstavo sam postane tragična zavest. ${ }^{1}$

Nič hudega, če Klasiki na odru niso bili tako gledališče - za to so potrebne izkušnje in znanje. Poznavanje grškega in rimskega gledališča pa je, če ocenim na počez, pri Slovencih še slabše od poznavanja grške in rimske dramatike. Dijaki pri domačem branju preberejo le Antigono, pa še to jo le preberejo - možnosti, da bi jo doživeli tudi kot gledalci, so zelo redke -, v splošnih predstavah o dejanski uprizoritvi Antigone oz. katerega koli dramskega besedila iz antike pa se bohotijo koturni, helenistične maske in bogovi iz strojev. Celo med gledališko izobraženimi ljudmi! Škoda, kajti ta besedila nudijo svojevrstno soočenje $\mathrm{z}$ začetki dramatike, gledališča in demokracije, s temelji zahodne evropske civilizacije.

Kje torej začeti z dramsko in gledališko vzgojo, če ne pri Ajshilu, Sofoklu, Evripidu in Aristofanu? Kako jo nadaljevati, če ne z Menandrom, Plavtom, Terencijem in Seneko?

Zato smo zasnovali še en dramsko-gledališki projekt in ga poimenovali Replike $i z$ antike. Bojda antične dramatike nihče ne bere - saj konec koncev niti ni bila napisana za branje -, pa naj jo vsaj poslušajo, smo si rekli, sploh če jo interpretirajo profesionalni igralci. Naj za vas na glas bere gledališče! Za začetek smo izbrali Ajshilove Pribežnice v prevodu Braneta Senegačnika (Mohorjeva založba, 2008), Sofoklovega Ajanta v prevodu Kajetana Gantarja (Obzorja, 2000) in Evripidovo Heleno v prevodu Jelene Isak Kres (Modrijan, 2006). V SNG Drama so bili nad projektom navdušeni in ga takoj uvrstili na program Male drame - za vsako branje smo imeli dve do tri vaje

Jean-Pierre Vernant, »Napetost in dvoumnost v grški tragediji II«, v: J.-P. Vernant in P. VidalNaquet, Mit in tragedija v stari Grčiji, prev. Suzana Koncut in Agata Šega (Ljubljana: ŠOU, 1994), 28. 
in dve ponovitvi -, zdaj pa snujemo že spomladansko trilogijo (Heraklova blaznost, Alkestida, Trahinke).

Koncertna branja seveda niso take vrste gledališki dogodek, ki bi dosegal zgoraj omenjene zahteve dobrega gledališča in nikar mi ne zameri, če sem jih v začetku tako spektakularno navedla poleg pravih gledaliških uprizoritev; ker igralci besedila berejo sedeč za notnimi stojali, bi Replike iz antike zlahka poimenovali tudi literarni večeri ali recitali, po drugi strani pa vendarle gre za uprizoritve, saj sedijo na odru dramski igralci in vloge interpretirajo ... Danes je pač tako, da si natisnjene replike lasti literatura, uprizorjene pa gledališče. Knjiga je večna, predstava enkratna. Ampak to enkratnost so tvoji najstarejši sinovi razumeli dobesedno (kasneje so se enkratni gledališki dogodki posrečili še Artaudu, pa še to bolj po nesreči, ker niso uspeli ...). Danes imamo reprize in cel kup od gledališča kratkočasnejših medijev, zato si tega, da je bilo v petem stoletju pr. Kr. v Atenah uprizorjenih okoli tisoč tragedij, od katerih je bila vsaka uprizorjena le enkrat (!), ne morem predstavljati. Res, včasih so si znali vzeti čas, je po zadnji vaji za Ajanta sklenil Odisej Zrnec.

No ja, mnogo je stvari, ki si jih ne morem predstavljati, in nikoli ne bom vedela, kako so bile videti uprizoritve Pribežnic, Ajanta, Helene in drugih. Historična reprodukcija me ne zanima - niti ni mogoča -, ker pa verjamem v soodvisnost forme in vsebine, sem prepričana, da je dobro in prav vedeti vsaj tisto, kar lahko vemo. Kajti šele potem je mogoč resen dialog, konstruktiven konflikt, dobro gledališče. Ko vem, da nič ne vem. Danes pa - kaj vse ljudje mislimo, da vemo ... ne bi mi verjela.

Z dobro srečo, Jera 